\section{IN SITU OBSERVATIONS ON THE HABITAT AND ABUNDANCE OF THE SQUAT LOBSTER GASTROPTYCHUS PERARMATUS (HAIG, 1968) (CRUStaCEA: DeCAPOdA: ChIROSTYLIDAE) IN THE NORTHERn GUlF OF CALIFORNIA, MEXICO}

\author{
Michel E. Hendrickx ${ }^{1}$, Alejandro Hinojosa ${ }^{2}$ \& Manuel Ayón-Parente ${ }^{3}$
}

${ }^{1,3}$ Laboratorio de Invertebrados Bentónicos, Unidad Académica Mazatlán, Instituto de Ciencias del Mar y Limnología, Universidad Nacional Autónoma de México, P.O. Box 811, Mazatlán, Sinaloa, 82000, Mexico

${ }^{2}$ División de Ciencias de la Tierra, CICESE, Carret. Ensenada-Tijuana 3918, Ensenada, B.C. 22860, Mexico

${ }^{1}$ michel@ola.icmyl.unam.mx (corresponding author), ${ }^{2}$ alhinc@cicese.mx, ${ }^{3}$ manuel_aparente@hotmail.com

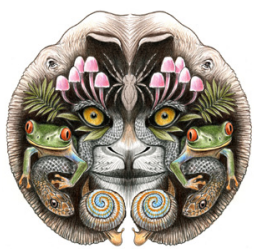

ISSN

Online 0974-7907

Print 0974-7893

\begin{abstract}
Living specimens of Gastroptychus perarmatus (Haig, 1968), a chirostylid squat lobster, were observed on colonies of gorgonian corals and sponges in the northern Gulf of California. Video footage and photographs obtained from the Remotely Operated Vehicle JASON dive north of Angel de La Guarda Island in the northern Gulf of California indicate that this Squat Lobster lives on coral specimens of Callogorgia, probably C. flabellum (Ehrenberg, 1834), and on one or two unidentified species of sponge(s). Seven sites were observed to contain $G$. perarmatus with the number of individuals per host varying from 2 to 11 . No specimens were observed on the sea floor away from a host. Review of videos indicates that most individuals of $G$. perarmatus observed remained motionless in the same position throughout the video recording period (max. 30 seconds), with the body erect and the chelipeds extended, presumably to facilitate collection of organic particles transported by the current. At one site, however, the video shows one adult specimen grasping large particles of floating debris retained on the gorgonian. Until recently there were no records of $G$. perarmatus since it was described from California in depths of $229 \mathrm{~m}$ (north of Anacapa Island). A few specimens were accidentally captured in a benthic sledge in the northern Gulf of California in 2011. This is a new record for the area, including a new maximum depth record (705-710 $\mathrm{m}$ ) for the species. This rare species of squat lobster and its host the gorgonian coral would be subject to severe environmental impacts if fishing or mining activities were developed in the area.
\end{abstract}

Keywords: Callogorgia, Chirostylidae, Gastroptychus perarmatus, Gulf of California, in situ observation.

DOI: http://dx.doi.org/10.11609/JoTT.o3133.5228-36 | ZooBank: urn:Isid:zoobank.org:pub:E718AF17-6818-45C1-98B1-89933E1739D5

Editor: Kareen Schnabel, NIWA, Wellington, New Zealand

Date of publication: 26 December 2013 (online \& print)

Manuscript details: Ms \# 03133 | Received 24 March 2012 | Final received 22 October 2013 | Finally accepted 15 November 2013

Citation: Hendrickx, M.E., A. Hinojosa \& M. Ayón-Parente (2013). In situ observations on the habitat and abundance of the squat lobster Gastroptychus perarmatus (Haig, 1968) (Crustacea: Decapoda: Chirostylidae) in the northern Gulf of California, Mexico. Journal of Threatened Taxa 5(17): 5228-5236; http://dx.doi. org/10.11609/JoTT.03133.5228-36

Copyright: ( ) Hendrickx etal. 2013. Creative Commons Attribution 3.0 Unported License. JoTT allows unrestricted use of this article in any medium, reproduction and distribution by providing adequate credit to the authors and the source of publication.

Funding: SEMARNAT-CONACYT (Project 107418), "Caracterización del fondo marino en las cuencas abisales y escarpes de fallas transformes en el golfo de California"

Competing Interest: The authors declare no competing interests.

Author Details and Contriction: MICHEL E. HENDRICKX - Marine Biologist, PhD, expert in crustaceans and other invertebrates of the eastern Pacific. Head scientist of the TALUD project. Interpretation and identification of the biological material on the video used in this contribution. Senior redactor of the contribution. ALEJANDRO HINOJOSA - Marine Geologist, MSc, expert in Mexican Pacific geology and marine oceanography. Participant in the JASON cruise and head of the CICESE project dealing with the video footage taken by the JASON. MANUEL AYON-PARENTE - Marine Biologist, PhD, expert in decapod crustaceans. Member of the TALUD cruises staff. Revision and edition of photographs used in this contribution.

Acknowledgements: We thank Peter Lonsdale, SCRIPPS Institution of Oceanography, for making available the graphic material taken by the ROV JASON, operated from the R/V "Atlantis". We acknowledge SEMARNAT-CONACYT for supporting the study of the JASON video footages (project 107418). We thank the students Luis A. Duarte, Abril Pérez, Yesenia González, Cristina Quezada, Pamela Flores, Fernanda Pares and Pablo Echevarria for their dedicated and persistent effort exploring the many hours of the ROV submarine videos and systematically registering observations. We also thank Stephen Cairns, Smithsonian Institution, for providing some clues related to the identification of Callogorgia.
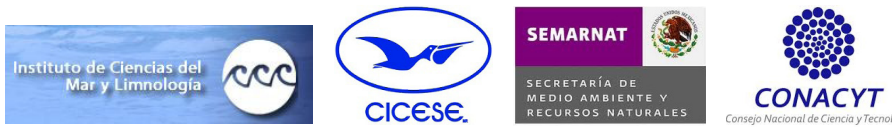


\section{INTRODUCTION}

Direct observations of deep water invertebrate communities rely on the use of manned-submersibles or on remotely operated vehicles (ROV) that transmit videos and photographs to the surface (Gage \& Tyler 1992). Although specimens are rarely available for direct study in the laboratory, the shape, size and colours of the organisms spotted by the submersible crew or observed on videos and photographs are sometimes sufficient to provide a positive identification. This will depend on the skill of the taxonomists involved and on the general knowledge they have of the local fauna. Selected sampling in the same area, either during dives (i.e., specimens collected in baskets, tubes or traps) or by traditional methods (e.g., trawling and dredging from ocean-going vessels), are often key to a correct identification.

The squat lobster fauna off the Pacific coast of America consists of 77 species, with the genera Munida (mostly found on the continental platform) and Munidopsis (from the upper slope downwards) being the most speciose in the area (Hendrickx 2003a,b, 2012a; Baba et al. 2008). Only seven species of the family Chirostylidae have been reported for the region, including four species of Gastroptychus (Baba et al. 2008; Hendrickx 2012a). One of these, G. perarmatus (Haig, 1968), previously known only from its type locality off California, USA, was recently rediscovered in the northern Gulf of California based on one sample collected with a benthic sledge by the R/V "El Puma" of the Universidad Nacional Autónoma de México (Hendrickx 2012a). Simultaneously, with the study of this freshly collected material, a series of video transects from the same area was made available to us and clearly shows the presence of $G$. perarmatus in a very restricted habitat at ca $710 \mathrm{~m}$ depth.

Information on distribution and habitat of rare species, including deep-water organisms, is particularly interesting as it provides valuable data for conservation and management for these areas. Among vulnerable marine ecosystems (VMEs), deep-water communities are particularly fragile because of their low metabolism and their limited recruitment pattern (Gage \& Tyler 1992; Levin 2003). This report is based on the detailed examination of videos and selected photographs taken during the operations of the ROV JASON in the northern Gulf of California.

\section{MATERIAL AND METHODS}

The project "Caracterización del Fondo Marino en las Cuencas Abisales y Escarpes de Fallas Transformes del Golfo de California" ["Sea floor characterization on the Abyssal Basins and Transform Faults escarpments of the Gulf of California"] was initiated by CICESE (Ensenada, Mexico) in 2011. The aim of this project was to investigate a comprehensive series of photographs and video footage taken by a ROV throughout the Gulf of California during May 2008, at depths between 380 and $3747 \mathrm{~m}$. The cruise, organized by the Scripps Institution of Oceanography (SIO) with Professor Peter Lonsdale as the leading scientist, performed 26 dives at 19 different localities deploying the ROV JASON from the Woods Hole Oceanographic Institution R/V "Atlantis". The ROV collected rock samples, captured digital photographs and recorded continuous video during the dives, providing a total of ca 400 hours of video for each of the three cameras that were used simultaneously once the gear was near the bottom. The videos were carefully examined by a team of trained undergraduate students, systematically registering observations and capturing video frames where organisms could be spotted for their future examination by experts. Video frame grabs were captured at video resolution ( $720 \times 540$ pixels), a lower quality product than the digital photographs of selected targets at 3 Megapixels resolution (2048x1535 pixels). Reference material and colour photographs of specimens obtained at a similar depth range in the same area during a 2011 research cruise (see Hendrickx 2012b) were used while reviewing video footage from which the images of specimens were captured.

From the JASON's log, with at least one automatic entry every minute and additional ones when special events occurred, it was possible to assign depth and geographic position to the photographs and frame grabs from the video, in addition to other physical parameters at depth from ROV sensors (temperature, conductivity, pressure). All spatial measurements were estimated using a pair of collimated laser beams at $10 \mathrm{~cm}$ on board the ROV, projecting the reference points on bottom targets. On dive J2-337 on the Lower Delfin Basin, NW of Angel de La Guarda Island, the ROV captured the occurrence of Gastroptychus specimens between 660 and $710 \mathrm{~m}$. The identification of the squat lobster was made possible by using fresh specimens of the genus Gastroptychus previously collected in roughly the same area (northern Gulf of California) by the R/V "El Puma" of the Universidad Nacional Autónoma de México at $\sim 430 \mathrm{~m}$ depth using trawl gear. This contribution reports 
on the specific habitat and local distribution of this rare species of squat lobster.

\section{RESULTS}

The $12-337$ dive, the $12^{\text {th }}$ for this expedition, was the farthest north into the Gulf of California (Image 1A) and also the longest one, with more than 22 hours of immersion vs. 16 hours in average for the rest of the 25 dives. It started on 12 May 2008 at 21:57 and ended on 13 May at 20:11 GMT. The purpose for this dive was to explore the northern scarps of the Lower Delfin Basin, a depression associated with the extensional tectonics in the northern Gulf, with a dense complex network of mainly ENE trending oblique-normal faults cutting the stratigraphy (Persaud et al. 2003). The graphic material was collected by the cameras of the ROV JASON along

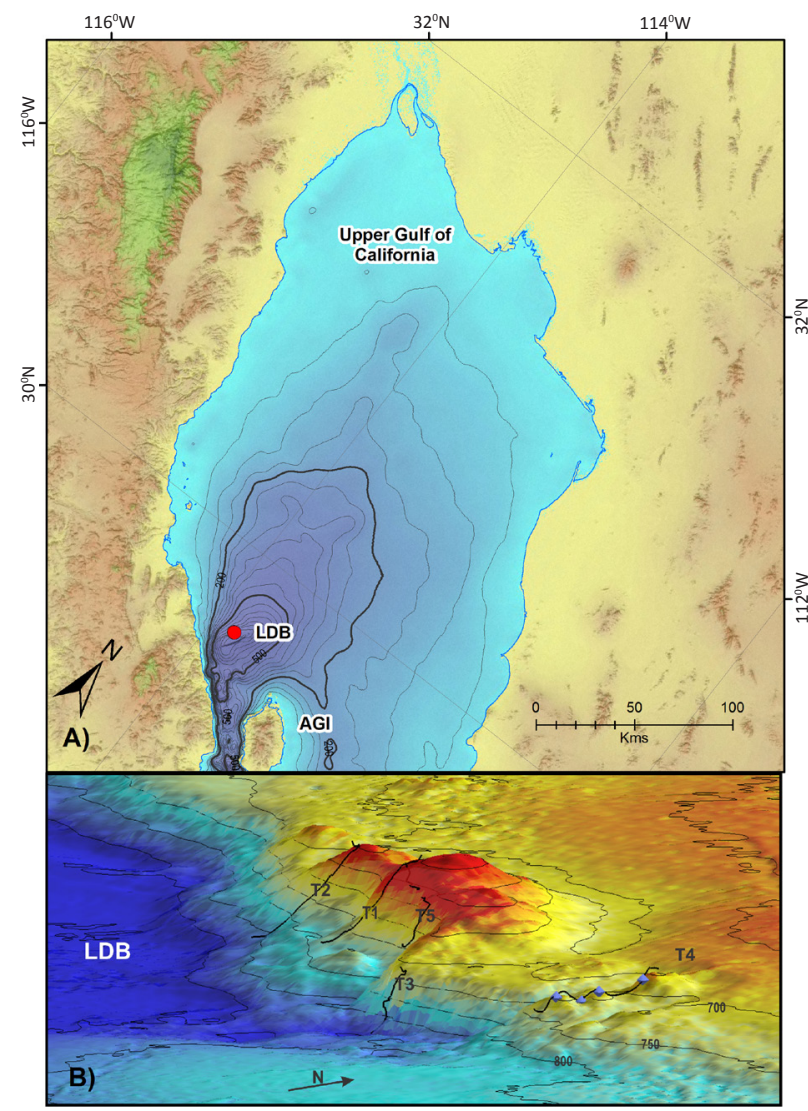

Image 1. A - The red circle indicates the location of JASON ROV dive (J2-337) at the Lower Delfin Basin (LDB) in the upper Gulf of California, NW of Angel de la Guarda Island (AGI) where specimens of Gastroptychus perarmatus (Haig, 1968) were observed; B - The location of the five transects of the ROV along ascents over the seamounts on the northern flank of axial trough of the LDB. The blue symbols indicate observations of $G$. perarmatus during transect 4 (T4) which traversed three volcanic knolls. ascents over the seamounts on the northern flank of axial trough of the Lower Delfin Basin. The ROV traversed five transects over scarps of volcanic edifices (Image 1B).

Observations of the Gastroptychus occurred on transect number 4 (T4) (Image 1B), the furthest to the east, along a path $938 \mathrm{~m}$ long that traversed three volcanic knolls, less prominent than the steep ascents of other transects for this dive. T4 with a predominant WNW heading, lasted for 2:30 hours, starting at a depth of $735 \mathrm{~m}$ and traversing at an average of $2.5 \mathrm{~m}$ above the sea floor (Images 1B, 2A). The temperature registered on JASON's log was stable with an average of $11.8^{\circ} \mathrm{C}$. There were no encounters along the first $200 \mathrm{~m}$ of $\mathrm{T} 4$ path. The initial Gastroptychus perarmatus appeared near the peak of the first knoll, close to the $700 \mathrm{~m}$ depth contour in Image 2A. From this point and along the next $600 \mathrm{~m}$ (Image 2B), there were six more encounters and digital photos were captured of Gastroptychus perarmatus at all seven sites (Images 3,4 ). It was possible to confirm the presence of this species of squat lobster on each photograph and show them perched on different colonies of gorgonians and sponges (Table 1). Comparison with the material collected during the TALUD cruise leaves no doubt that the species found on the gorgonians and sponges is $G$. perarmatus (Haig, 1968). Colour and general morphology observed on the photographs match perfectly with the collected specimens (see Hendrickx 2012a). Photographic records (Images 3,4) are new evidence of the presence of $G$. perarmatus in the Gulf of California and extend its known distribution range to the north to $29^{\circ} 42^{\prime} 04^{\prime \prime} \mathrm{N} \& 113^{\circ} 53^{\prime} \mathrm{W}$ (previous record: $\left.28^{\circ} 10^{\prime} 05^{\prime \prime} \mathrm{N} \& 112^{\circ} 31^{\prime} 59^{\prime \prime} \mathrm{W}\right)$, roughly by 115 nautical miles (about $210 \mathrm{~km}$ ). Previous depth records are $229 \mathrm{~m}$ (type locality) and 435-451 m (TALUD material) (Haig 1968; Hendrickx 2012a), and the data obtained from the JASON dive increase the maximum known depth of this species to $710 \mathrm{~m}$.

The identification of the Gorgonacea was more difficult as there is no comparative material available. Close examination of photographs taken during the JASON dives indicate that $G$. perarmatus is associated with gorgonians of the family Primnoidae. According to Brusca \& Trautwein (2005), there is only one species of this family known from the Gulf of California, Callogorgia flabellum (Ehrenberg, 1834) (type locality unknown), occurring from off Guaymas, Sonora, to Cabo Corrientes, Jalisco, Mexico, and also known in the western Pacific (Bayer 1982; Brusca \& Trautwein 2005). The Gulf of California distribution is based on four records of $C$. flabellum (Brusca \& Hendrickx 2008) (Table 2). Other records, however, indicate that $C$. flabellum also occurs 


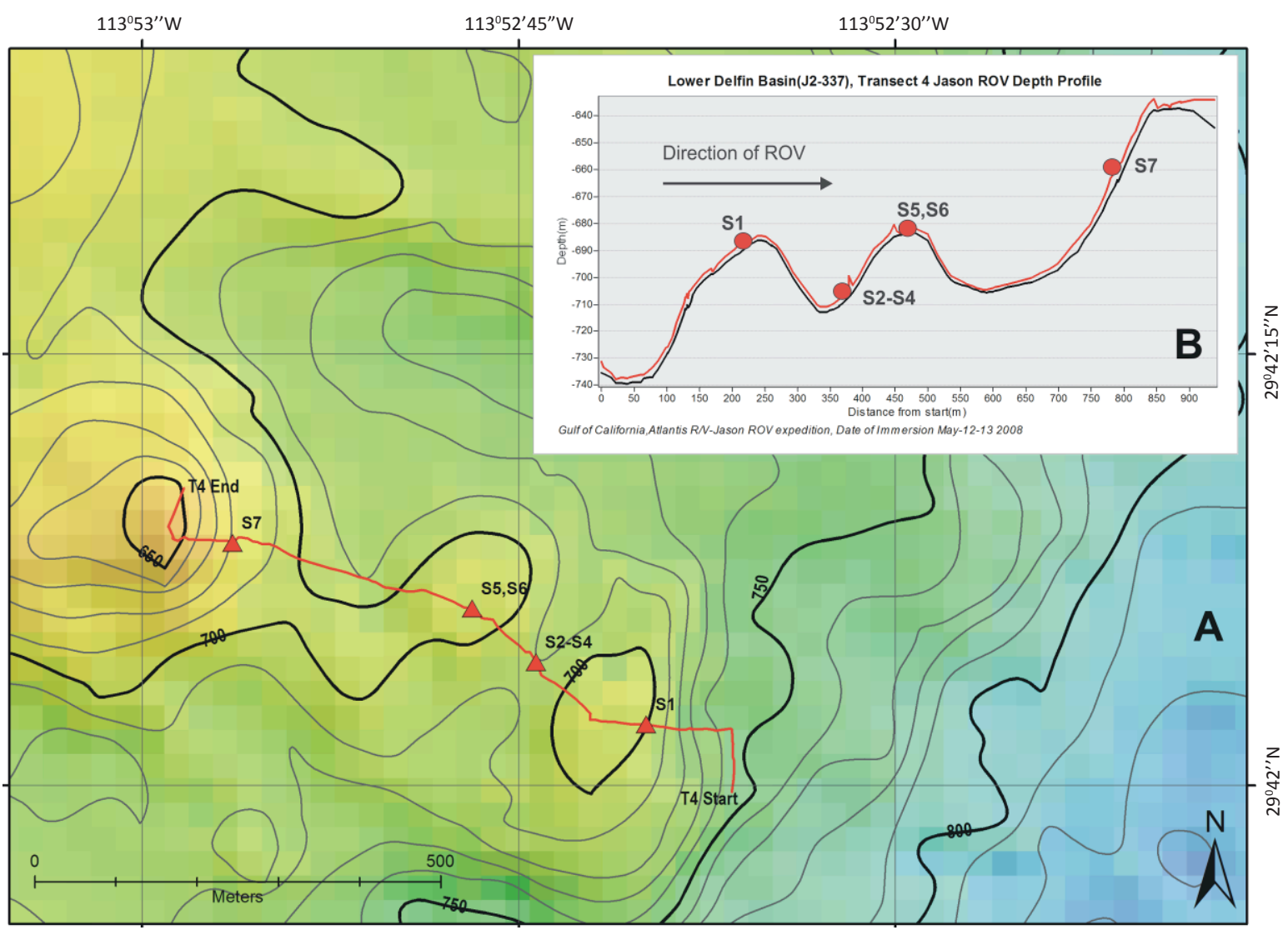

Image 2. A - Transect 4 (T4, dive J2-337) of ROV with a predominant WNW heading, starting at a depth of $735 \mathrm{~m}$ and traversing three volcanic knolls at an average of $\mathbf{2 . 5 m}$ above sea floor. The location of Gastroptychus perarmatus sites in Table 2 is indicated with red triangles.

B - ROV depth profile along T4, line in red is the depth of the ROV and in black the depth of sea floor as registered by the JASON's log. Sites 2 to 4 and 5 to 6 are grouped since they are too close at the graphic scale used.

Table 1. Sites where Gastropthychus perarmatus was observed during the JASON J-337-2 dive (transect T4) in the Gulf of California, Mexico. Available environmental data and number of squat lobsters on each host are indicated. NA = not available.

\begin{tabular}{|c|c|c|c|c|c|c|c|c|}
\hline Code & $\begin{array}{l}\text { Photos ref. } \\
\text { number }\end{array}$ & Time & Lat. N & Long. W & Depth & Name of host & $\begin{array}{l}\text { Size of host (wide } x \\
\text { height in } \mathrm{m} \text { ) }\end{array}$ & $\begin{array}{l}\text { Number of } G \text {. } \\
\text { perarmatus }\end{array}$ \\
\hline Site 1 & NA & $13: 20: 40$ & 29.7006 & 113.8780 & $690 \mathrm{~m}$ & $\begin{array}{l}\text { Callogorgia cf. flabellum on } \\
\text { isolated rock (ca } 0.8 \mathrm{~m} \text { wide) }\end{array}$ & $0.5 \mathrm{~m} \times \mathrm{NA}$ & 1 specimen \\
\hline Site 2 & (448) & $13: 42: 19$ & 29.7011 & 113.8789 & $709 m$ & $\begin{array}{l}\text { Callogorgia cf. flabellum on } \\
\text { isolated rock (ca } 1.8 \mathrm{~m} \text { wide) }\end{array}$ & $0.8 \mathrm{~m} \times \mathrm{NA}$ & 5 specimens \\
\hline Site 3 & NA & $13: 42: 56$ & 29.7011 & 113.8789 & $710 \mathrm{~m}$ & $\begin{array}{l}\text { Encrusting sponge on isolated } \\
\text { rock (ca } 0.2 \mathrm{~m} \text { wide) }\end{array}$ & $0.5 \mathrm{~m} \times \mathrm{NA}$ & 1 specimen \\
\hline Site 4 & (449) & $13: 43: 49$ & 29.7012 & 113.8790 & $708 m$ & $\begin{array}{l}\text { Callogorgia cf. flabellum on } \\
\text { isolated rock (ca } 1.8 \mathrm{~m} \text { wide) }\end{array}$ & $2.0 \mathrm{~m} \times 1.0 \mathrm{~m}$ & 11 specimens \\
\hline Site 5 & NA & $13: 57: 08$ & 29.7016 & 113.8795 & $682 m$ & $\begin{array}{l}\text { Callogorgia cf. flabellum on } \\
\text { isolated rock (ca 2.0m wide) }\end{array}$ & $0.8 \mathrm{~m} \times \mathrm{NA}$ & 4 specimens \\
\hline Site 6 & (455) & $14: 05: 30$ & 29.7017 & 113.8797 & $680 \mathrm{~m}$ & $\begin{array}{l}\text { Callogorgia cf. flabellum on } \\
\text { isolated rock (ca } 0.8 \mathrm{~m} \text { wide) }\end{array}$ & $0.8 \mathrm{~m} \times 0.5 \mathrm{~m}$ & 2 specimens \\
\hline Site 7 & (457/458) & $14: 50: 34$ & 29.7023 & 113.8823 & $660 \mathrm{~m}$ & $\begin{array}{l}\text { Encrusting sponge on large rocky } \\
\text { escarpment }\end{array}$ & $0.8 \mathrm{~m} \times 0.7 \mathrm{~m}$ & 5 specimens \\
\hline
\end{tabular}

along the western coast of the Baja California Peninsula, off Bahía Magdalena $\left(24^{\circ} 05^{\prime} \mathrm{N} \& 113^{\circ} 20^{\prime} \mathrm{W}\right)$ (GBIE, 2008), and in a more northerly locality in the Gulf of California (Parker 1964) (Table 2). In situ photographs of $C$. flabellum available in published documents are rare and we could only locate one (Tokeshi 2003). This author indicates that this gorgonian is whitish, with widely expanded upper branches, very similar to the specimens seen on the JASON dive photographs (Images $3 \mathrm{~A}, \mathrm{~B})$. Examination of the best photograph available 

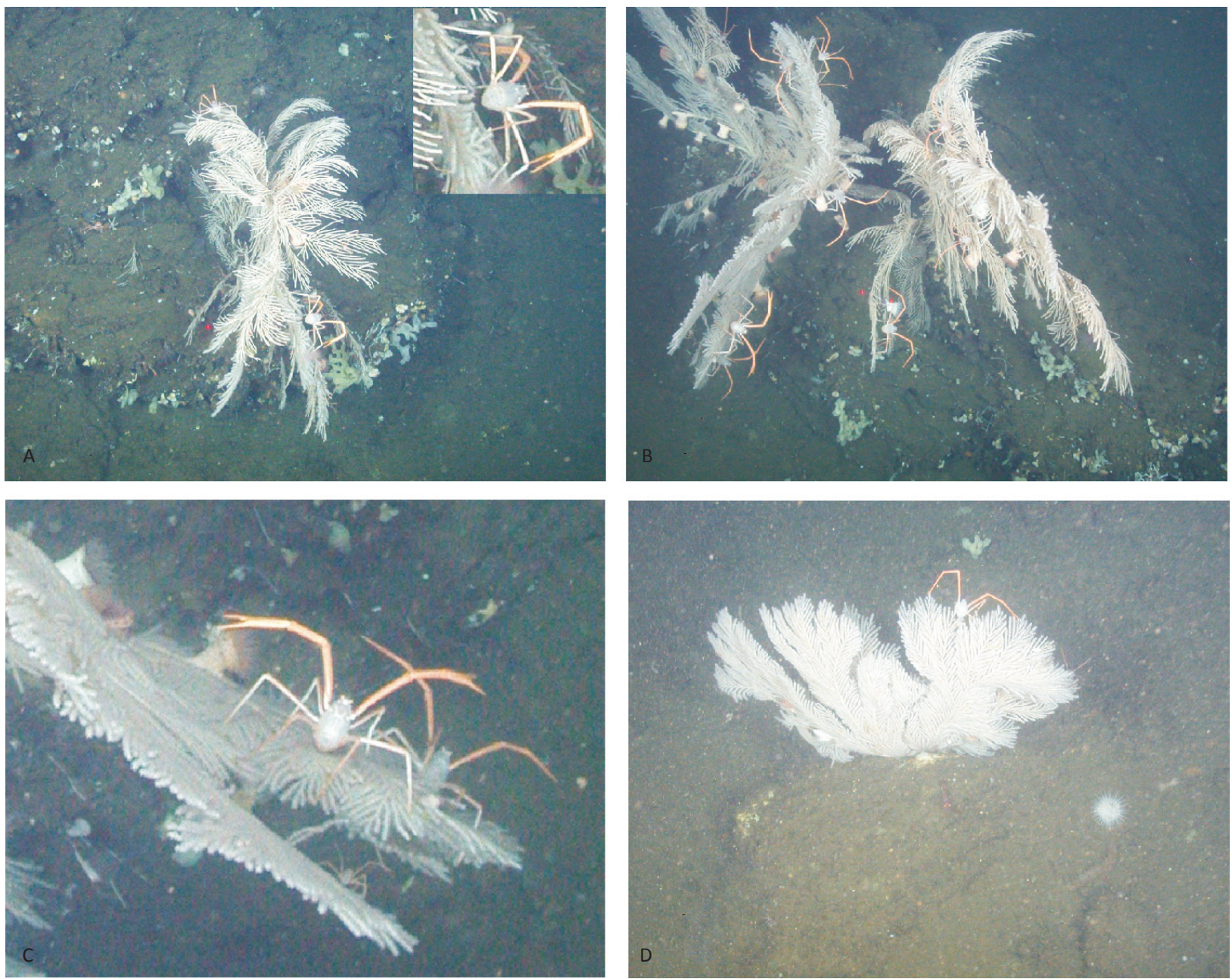

Image 3. Photographs obtained from the digital camera at 3 Mpixels taken by the JASON ROV during transect T4 (dive J2-337) in the Gulf of

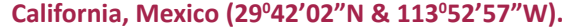

A - Site 2. Gastroptychus perarmatus on Callogorgia cf. flabellum, 709m depth (ref. photo 448); insert, adult specimen taking food to the mouth (video frame grab P080513134220); B - Site 4, G. perarmatus on C. cf. flabellum, 708m depth (ref. photo 449); C - Same as B, close-up of an adult specimen of G. perarmatus; D - Site 6, G. perarmatus on C. cf. flabellum, 680m depth (ref. photo 455).

indicates that the gorgonians hosting G. perarmatus are very likely to be Callogorgia (S. Cairns, pers. comm., June 2011) and is very close to $C$. flabellum.

Identification of sponges (Image 4) used as habitat by G. perarmatus, even to genus-level, is almost impossible as there is very little information on deep-water sponges in the Gulf of California, and known species have not been photographed live. In addition, sponges are particularly plastic, and the same species can grow in very different ways (small to very large; compact or ramified) (Willenz et al. 2009).

The number of specimens of $G$. perarmatus on a single colony of gorgonian varied from a maximum of 11 (Image 3B) to a minimum of two (Image 3D). Video footages indicate that all specimens observed were either adults or subadults, with little difference in size.
Table 2. Records of Callogorgia flabellum (Ehrenberg, 1834) in the eastern Pacific. Include depth, include gear used.

\begin{tabular}{|l|l|l|}
\hline Locality & Coordinates & Source \\
\hline Gulf of California & $29^{\circ} 42^{\prime} \mathrm{N} \& 113^{\circ} 53^{\prime} \mathrm{W}$ & Parker 1964 \\
\hline Gulf of California & $27^{0} 53^{\prime} \mathrm{N} \& 110^{\circ} 52^{\prime} \mathrm{W}$ & Brusca \& Hendrickx 2008 \\
\hline Gulf of California & $24^{\circ} 16^{\prime} \mathrm{N} \& 110^{\circ} 20^{\prime} \mathrm{W}$ & Brusca \& Hendrickx 2008 \\
\hline Gulf of California & $22^{\circ} 53^{\prime} \mathrm{N} \& 109^{\circ} 55^{\prime} \mathrm{W}$ & Brusca \& Hendrickx 2008 \\
\hline Cabo Corrientes & $20^{\circ} 24^{\prime} \mathrm{N} \& 105^{\circ} 42^{\prime} \mathrm{W}$ & Brusca \& Hendrickx 2008 \\
\hline California Current & $24^{\circ} 05^{\prime} \mathrm{N} \& 113^{\circ} 20^{\prime} \mathrm{W}$ & GBIE 2008 \\
\hline
\end{tabular}

It was not possible, however, to distinguish males from females. On the three sponges that were observed, 1-5 specimens could be spotted (Image 4A). Most specimens were observed in the same position, with their body held erect and the chelipeds (first pair of pereiopods) 


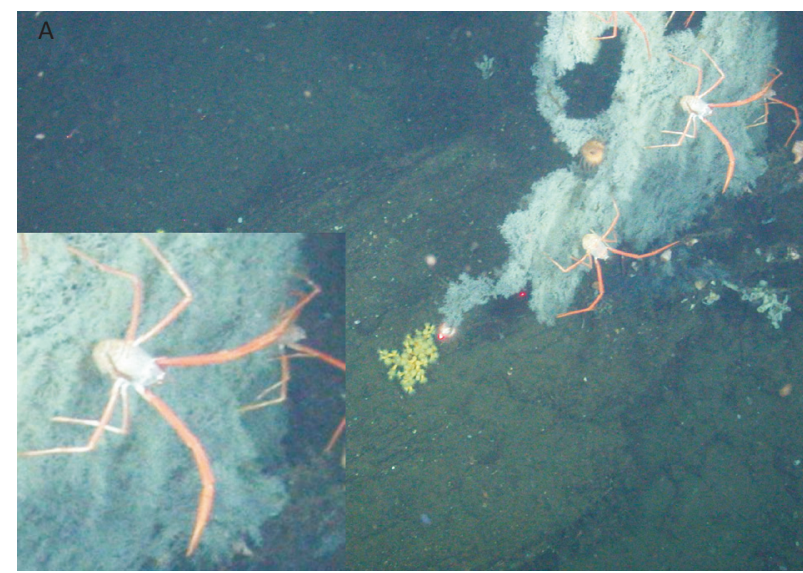

Image 4. Photographs taken with a digital camera at 3 Mpixels by the JASON ROV during T4 (J2-337) dive in the Gulf of California,

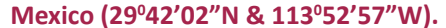

A - Site 7. Gastroptychus perarmatus on unidentified sponge, $660 \mathrm{~m}$ depth (ref. photos 457-458). Inset, enlarged specimen.

extended upwards and bending outwards, forming a gentle curve (Image 3C). Review of video footages shows that the specimens are usually motionless, located on the side of the host (gorgonians or sponges) and exposed to the current. However, in one sequence, one large specimen of $G$. perarmatus located on a gorgonian clearly moves its cheliped and picked up what appears to be a large particle of material from the coral and takes it to its mouth (Image $3 \mathrm{~A}$, insert). The video shows that many large floating particles are retained by the gorgonian's ramifications or by the sponges, thus indicating that $G$. perarmatus takes advantage of this passive filtering role to feed on large particles of debris. At the same time, this probably helps the coral in not being smothered by accumulating debris. Not a single specimen of $G$. perarmatus was observed on the sea floor sediments in the entire 55 minute transect, not even in close proximity of the gorgonians or the sponges, thus indicating that this squat lobster is probably an obligate commensal of these sessile organisms.

In the vicinity of the gorgonians, several specimens of another squat lobster were observed (Image 2A), but their identification remains difficult. In site S2, two specimens of what seems to be Janetogalathea californiensis (Benedict, 1902) can be observed, at about $0.2-0.3 \mathrm{~m}$ from the gorgonian. Also, some unidentified sea stars and a few colonies of unidentified sponges are observed very close to the coral. In the unique sample of $G$. perarmatus collected during the TALUD project with a benthic sledge, specimens of J. californiensis and of Munida bapensis Hendrickx, 2000, were also found, but no specimens of Callogorgia were collected (see
Hendrickx 2012a). Both squat lobster species feature a reddish or dark-orange carapace, as do the specimens spotted around $C$. cf. flabellum on the video (Video 1). The size (moderately long) and shape (somewhat flattened) of the chelipeds of the specimens observed on the video footage are also more typical of J. californiensis and Munida bapensis.

\section{DISCUSSION AND CONCLUSIONS}

There is a large amount of data related to samples of invertebrates collected in the Gulf of California intertidal and shallow-water habitats (see Brusca 1980; Hendrickx et al. 2005). On the contrary, deep-water habitat, particularly below $500 \mathrm{~m}$ depth, has been scarcely sampled. Between 2000 and 2011, the TALUD project visited over 150 stations in the Gulf of California and 125 benthic sledge samples were obtained between about 300 and 2300 m depth (see Hendrickx 2012b). A sample of $G$. perarmatus was collected on one occasion only, but most samples were performed over flat, muddy bottoms, with little or no rocky substrate.

Considering that $G$. perarmatus had never been collected again since its description in 1968, probably due to absence of sampling at depths where it primarily occurs, it is notable that, in only a few months of time, we were able to not only collect fresh material of this rare species with a benthic sledge (see Hendrickx 2012a) but also had the opportunity to capture images of the same species at ca $700 \mathrm{~m}$ depth in the same area. If the transect monitored in this survey is representative of the biocoenosis in this area of the Gulf of California, the density of $G$. perarmatus is set at 28 organisms in the $600 \mathrm{~m}$ path. Although the ROV did not maintain a constant distance to the bottom, the width of the field filmed during the survey averaged $3-4 \mathrm{~m}$, thus providing an estimated density of ca 133 organisms per hectare (28 organims/600m path $\times 3.5 \mathrm{~m}$ width/10000 square $\mathrm{m}$ per hectare). This density of organisms is difficult to establish for the entire length of $\mathrm{T} 4$, since there were blind segments when JASON ROV was descending along the volcanic knolls (Image $2 \mathrm{~B}$ ), projecting lights into the deep along the descending path, not illuminating the sea floor and most probably missing some specimens. All of the encounters were on the ascending and flat segments of T4 traversal (Image 2B).

Considering the scarcity of records for $G$. perarmatus in the area, and the fact that both currently known sampling localities of this species within the Gulf of California are separated by a relatively long distance, it 
is difficult to evaluate how extensive its distribution is and how densely distributed it is. In the video footages that were reviewed for all the dives there was no sign of the presence of $G$. perarmatus except on the colonies of Callogorgia that were spotted and, within the limits of what could be perceived, only adults and subadults occur on the coral. The habitat of juveniles remains therefore unknown.

The presence of $G$. perarmatus in the northern Gulf of California and off California might indicate that populations of this squat lobster may be found at suitable localities around the Baja California Peninsula. The substrate type where this species is supposed to occur (i.e., rocky substrate) make traditional sampling with trawl or dredges very risky and consequently uncommon. On the other hand, deep-water exploration using ROVs is very expensive and this type of equipment is not often available. There are large areas of the Mexican Pacific which remain virtually unexplored, particularly along the Baja California Peninsula rocky coast where Callogorgia or other similar species of gorgonian certainly occur.

Callogorgia flabellum has been recorded in the northern and southern Gulf of California and extends its distribution to Corrientes Cape, at the southern tip of the Bay of Banderas, west coast of Mexico. Parker (1964) reported C. flabellum at a depth range of 405602 m, between Angel de la Guarda Island and Roja Point $\left(29^{\circ} 04^{\prime} 42^{\prime \prime} \mathrm{N} \& 113^{\circ} 20^{\prime} 06^{\prime \prime} \mathrm{W}\right)$, a locality which is at about mid-length between the JASON and the TALUD records, thus reinforcing the hypothesis that this (or a closely related species) is relatively frequent. There was no report, however, of an associated squat lobster. Based on the information gathered during the JASON exploration it is impossible to precisely know how commonly this species might occur in the area.

In a preliminary report on $G$. perarmatus in the northern Gulf of California, Hendrickx (2012a) noted that only four other species of the genus have been found in the eastern Pacific (west coast of America): G. milneedwardsi (Henderson, 1885), from the type locality, in the Straits of Magellan, Chile; G. cavimurus Baba, 1977, from two localities, off Ecuador and Peru; G. defensus (Benedict, 1902), from the type locality, off the Galapagos Islands; and G. iaspis Baba \& Haig, 1990, from off British Columbia to western Mexico (Hendrickx \& Harvey 1999; Baba et al. 2008). The type material of Gastroptychus perarmatus was collected north of Anacapa Island, California, at a depth of $125 \mathrm{fm}$ (ca 230m) on muddy substrate. Despite of its size (total length $>21 \mathrm{~cm}$; Hendrickx 2012a), it had never been reported again. Gastroptychus milneedwardsi was collected at $732 \mathrm{~m}, \mathrm{G}$. cavimurus was trawled at 388 and $400-500 \mathrm{~m}$, and $G$. defensus at $717 \mathrm{~m}$ depth. Gastroptychus iaspis is definitively the species with the widest distribution range, from Mexico $\left(30^{\circ} 25^{\prime} 36^{\prime \prime} \mathrm{N} \& 122^{\circ} 43^{\prime} 42^{\prime \prime} \mathrm{W}\right)$ to Oregon ( $\left.46^{\circ} 02^{\prime} 42^{\prime \prime} \mathrm{N} \& 124^{\circ} 57^{\prime} 18^{\prime \prime} \mathrm{W}\right)$, and is reported in depths of 600-1189 m, and it was collected with rock dredge, traps, and shrimp trawl (Baba \& Haig 1990; Baba 2005; Baba et al. 2008). There is no information for any of these species on their precise habitat or possible associations with other organisms in the previously published literature.

The presence of another species of invertebrate associated to $C$. flabellum has been noted by Tokeshi (2003), who collected specimens of the ophiuroid Asteronyx loveni Müller \& Troschel, 1842, attached to the gorgonian at the An'ei Seamount, south of Japan, at $1477 \mathrm{~m}$ depth. Asteronyx loveni is also reported from deep water off the Pacific coast of Mexico (Maluf 1988), but there is no report of its association with gorgonians. Squat lobsters of the family Chirostylidae are often associated with soft corals (antipatharians, alcyonaceans, and gorgonians) (Baba 2005). However, biology and ecology of the deep-water members of this family is poorly known due to lack of direct access to their habitat.

The Oxygen Minimum Zone (OMZ) has a strong impact on species distribution along the Pacific coast of America (Helly \& Levin 2004) and particularly within the Gulf of California (Hendrickx \& Serrano 2010, 2013). The area where the specimens were observed by JASON, however, are located much further north and towards the northernmost limit of influence of the $\mathrm{OMZ}$ core (see Hendrickx \& Serrano 2013) and, although there were no in situ measurements of oxygen concentration associated with the JASON transect, it is very likely that oxygen was not an important limiting factor in this case. On the contrary, the material collected during the TALUD XIV cruise was obtained in severely hypoxic $(0.21 \mathrm{ml}$ $\mathrm{O}_{2} / \mathrm{l}$ ) environment, thus indicating a high tolerance to oxygen deficiency similar to what has been reported for several species of Galatheoidea occurring in the Gulf of California (see Hendrickx 2003b, 2012a).

The recent increase of exploration surveys using robotic equipment is rapidly changing our perception of the deep-water realm and more diverse, precise information is rapidly becoming available. As demonstrated again in this contribution, in the case of deep-water species of macrocrustaceans that occupyvery specific habitats, particularly in association with other invertebrates, direct observation using ROV or manned 
submersibles are the only reliable methods to gather information on their spatial coverage, behaviour and ecological niche. Ideally, these observations should be combined with selective and careful sampling using small traps or nets that would allow precise and authoritative identification. However, whenever possible, the use of a ROV to gather additional information on these peculiar species associations should be preferred as it represents a non-destructive method.

Due to a sharp decrease of fishing resources worldwide, areas previously considered of less interest or not easily accessible to traditional fishing gears are being explored. The northern Gulf of California is one of these areas. Fishery activity is very strong on the east and northern sections of the continental platform, but trawlers generally do not operate deeper than $120 \mathrm{~m}$. Below this depth the $\mathrm{OMZ}$ represents a physiological barrier for virtually all macro and mega fauna species, including commercial fishes (Hendrickx \& Serrano 2010). Due to decades of very strong pressure on resources in the area, however, stocks have been progressively diminishing and there are plans to explore the deeper habitats in search of exploitable resources. To this moment, the $\mathrm{OMZ}$ has represented an efficient obstacle for this exploration program. Indeed, in order to find potentially exploitable resources, trawls should operate below at least $300-800 \mathrm{~m}$, i.e., below the $\mathrm{OMZ}$ core, and the fleet is currently not properly equipped to do so. There is, however, a potential risk in case national fishery policy would consider supporting the development of commercial trawling in deep water. Proper management of natural resources in deep water should therefore consider protection of the habitats where rare species occur only in small number. As many other species associations in natural ecosystems, due to the fragility of both the squat lobster and the gorgonian coral, this community could be easily damaged by the action of sampling gears and care should be taken to protect this rare species from the destructive action of commercial fishing devices. Although not yet developed, potential seabed mining might be another threat in the future (see Sharma et al. 2001).

\section{REFERENCES}

Baba, K. (2005). Deep-sea Chirostylid and Galatheid Crustaceans (Decapoda: Anomura) from the Indo-Pacific, with a list of species. Scientific Results of the Danish Deep-Sea Expedition Round the World 1950-52. Galathea Reports 20: 1-317.

Baba, K. \& J. Haig (1990). A new species of chirostylid crustacean (Decapoda: Anomura) from off the west coast of North America. Proceedings of the Biological Society of Washington 104(4): 854-
860.

Baba, K., E. Macpherson, G.C.B. Poore, S.T. Ahyong, A. Bermudez, P. Cabezas, C.W. Lin, M. Nizinski, C. Rodríguez \& K.E. Schnabel (2008). Catalogue of squat lobsters of the World (Crustacea: Decapoda: Anomura - families Chirostylidae, Galatheidae and Kiwaidae). Zootaxa 1905: 1-220; http://dx.doi.org/10.1017/ S0025315411001895

Bayer, F.M. (1982). Some new and old species of the primnoid genus Callogorgia Gray, with a revalidation of the related genus Fanellia Gray (Coelenterata: Anthozoa). Proceedings of the Biological Society of Washington 95(1): 116-160.

Brusca, R.C. (1980). Common Intertidal Invertebrates of the Gulf of California. The University of Arizona Press, Tucson, Arizona, USA, 513pp.

Brusca, R.C. \& M.E. Hendrickx (2008). The Gulf of California Invertebrate Database: The Invertebrate Portion of the Macrofauna Golfo Database. http://www.desertmuseum.org/center/ seaofcortez/database.php

Brusca, R.C. \& S. Trautwein (2005). Cap. 4. Cnidaria and Ctenophora, pp. 49-65. In: Hendrickx, M.E., R.C. Brusca \& L.T. Findley (eds.). A Distributional Checklist of the Macrofauna of the Gulf of California, Mexico. Part I. Invertebrates. [Listado y Distribución de la Macrofauna del Golfo de California, México, Parte I. Invertebrados]. Arizona-Sonora Desert Museum. Tucson, Az, USA, 429pp.

Gage, J.D. \& P.A. Tyler (1992). Deep-Sea Biology: A Natural History of Organisms at The Deep-Sea Floor. Cambridge University Press, United Kingdom, 504pp.

Haig, J. (1968). First report of the crab family Chirostylidae off California, and description of a new species of Chirostylus. California Fish and Game 54(4): 270-277.

Helly, J. \& L.A. Levin (2004). Global distribution of naturally occurring marine hypoxia on continental margins. Deep-Sea Research I, 51: 1159-1168; http://dx.doi.org/10.1016/j.dsr.2004.03.009

Hendrickx, M.E. (2003a). The temperate species of the genus Munida Leach (Crustacea, Decapoda, Galatheidae) in the east Pacific, with the description of a new species and additional records for tropical-subtropical species. Bulletin de l'Institut Royal des Sciences Naturelles de Belgique 73: 117-138.

Hendrickx, M.E. (2003b). Geographic and bathymetric distributions of species of Munidopsis (Crustacea: Decapoda: Galathaeidae) in the SE Gulf of California, Mexico. Contributions to the Study of East Pacific Crustaceans 2. [Contribuciones al Estudio de los Crustáceos del Pacífico Este 2] Instituto de Ciencias del Mar y Limnología, UNAM 2, 21-30.

Hendrickx, M.E. (2012a). Squat lobsters (Crustacea: Decapoda: Galatheoidea and Chyrostyloidea) collected during the TALUD XIV cruise in the Gulf of California, Mexico, and rediscovery of Gastroptychus perarmatus (Haig, 1968) in the eastern Pacific. Zootaxa 3418: 28-40.

Hendrickx, M.E. (2012b). Operaciones oceanográficas en aguas profundas: los retos del pasado, del presente y del proyecto TALUD en el Pacífico mexicano (1989-2009), pp. 23-104. In: Zamorano, P., M.E. Hendrickx \& M. Caso (eds.). Biodiversidad y comunidades del talud continental del Pacífico mexicano. Secretaría del Medio Ambiente y Recursos Naturales (SEMARNAT), Instituto Nacional de Ecología (INE), Mexico D.F., 468pp.

Hendrickx, M.E. \& A.W. Harvey (1999). Checklist of anomuran crabs (Crustacea: Decapoda) from the Eastern Tropical Pacific. Belgian Journal of Zoology 129(2): 327-352.

Hendrickx, M.E. \& D. Serrano (2010). Impacto de la zona de mínimo de oxígeno sobre los corredores pesqueros en el Pacífico mexicano. Interciencia 35(1): 12-18.

Hendrickx, M.E. \& D. Serrano (2013). Effects of the oxygen minimum zone on squat lobsters distribution in the Gulf of California, Mexico. Central European Journal of Biology 9(1): 92-103; http://dx.doi. org/10.2478/s11535-013-0165-6

Levin, L.A. (2003). Oxygen minimum zone benthos: adaptation and community response to hypoxia. Oceanography and Marine Biology: an Annual Review 41: 1-45. 
Maluf, L.Y. (1988). Composition and abundance of the central eastern Pacific echinoderms. Technical Report, Natural History Museum of Los Angeles County 2: 1-242.

Parker, R.H. (1964). Zoogeography and ecology of some macroinvertebrates, particularly mollusks, in the Gulf of California and the continental slope off Mexico. Videnskabelige meddelelser fra Dansk naturhistorisk forening 126: 1-178.

Persaud, P., J. M. Stock, M. S. Steckler, A. Martín-Barajas, J. B. Diebold, A. González-Fernández \& G. S. Mountain (2003). Active deformation and shallow structure of the Wagner, Consag, and Delfín Basins, northern Gulf of California, Mexico. Journal of Geophysics Research 108(B7): 2355; http://dx.doi.org/10.1029/2002JB001937

Sharma, R., G. Parthiban \& S.J. Sankar (2001). Sediment redistribution during simulated benthic disturbance and its implications on deep seabed mining. Deep-Sea Research Part II: Topical Studies in Oceanography 48: 3363-3380.

Tokeshi, M. (2003). Habitat utilization by macrobenthos in deep-sea sandy fields: examples from the An'ei Seamount, Izu-Ogasawara. JAMSTIC Journal of Deep Sea Research 23: 87-97.

Willenz, P., E. Hadju, R. Desqueyroux-Faundez, G. Lóbo-Hadju \& M. de-Souza Carvalho (2009). Porifera - Sponges, pp. 93-94. In: Häussermann, V. \& G. Försterra (eds). Marine Benthic Fauna of Chilean Patagonia. Illustrated Identification Guide. Nature in Focus, Santiago, Chile, 1000pp.
Resumen: Especímenes vivos de Gastroptychus perarmatus (Haig, 1968), un langostino chirostilideo, fueron observados sobre colonias de corales blandos (gorgonas) y esponjas en el norte del golfo de California. Videos y fotografías, obtenidos durante inmersiones del vehículo operado por control remoto JASON al norte de la isla Angel de La Guarda, en el norte del golfo de California, indican que este langostino vive sobre especímenes del coral Callogorgia, probablemente $C$. flabellum (Ehrenberg, 1834), y en una o dos especies no identificadas de esponjas. En siete sitios se observo la presencia de $G$. perarmatus, con un número de individuos por huésped de entre 2 y 11 . No se observaron especímenes en el piso marino, fuera de los huéspedes. La revisión de los videos indica que la mayoría de los individuos de $G$. perarmatus permanecían inmóviles, en la misma posición, a lo largo de la toma (máx. 30 segundos), con el cuerpo erecto y los quelípedos extendidos, supuestamente para facilitar la recolección de partículas orgánicas transportadas por la corriente. Sin embargo, en uno de los sitios, el video muestra un espécimen adulto recogiendo grandes partículas de material retenido por la gorgona. Hasta recientemente, no se había registrado un nuevo hallazgo de G. perarmatus desde su descripción en California, a una profundidad de $229 \mathrm{~m}$ (al norte de la isla Anacapa). Algunos especímenes fueron capturados de manera accidental con un trineo bentónico en el norte del golfo de California en 2011. Se presentan nuevos registros para el área, incluyendo un nueva profundidad máxima de captura (705-710m) para esta especie. Esta especie rara de langostino y su huésped, el coral blando sobre el cual vive, podrían ser sujeto a un severo impacto ambiental en caso de que se desarrollará actividades pesqueras o mineras en el área. 